\title{
ENERGETIKAI KONCEPCIÓK A TÖBBEMELETES ACÉLSZERKEZETEK SZEIZMIKUS ELEMZÉSÉHEZ
}

\section{ENERGY STATE OF SEISMICALLY ACTED MULTI-STORY STEEL STRUCTURES}

\author{
Máthé Alíz Éva
}

Kolozsvári Müszaki Egyetem, Építömérnöki Kar, Tartószerkezetmechanikai Tanszék, Cím: 400020, Románia, Kolozsvár, C. Daicoviciu u., 15; Telefon +040-264-401345, aliz.mathe@mecon.utcluj.ro

\begin{abstract}
The intended study introduces energy state of seismically acted upon structures and enlarge the mechanical state expressed via the more traditional static and kinematic parameters. Energy state is expressed by two energy components: seismic induced energy and energy dissipated by inherent viscous damping. Some numerical results are presented associated to reference seismic actions of Romanian territory. Energy state is, also, related to the lateral rigidity of multi-story steel structures emphasizing a clear tableau of both, rigidity versus seismic input energy and rigidity versus dissipated energy. The research was funded by the Department of Structural Mechanics.
\end{abstract}

Keywords: seismic energy, steel structures, rigidity, seimic input energy.

\section{Összefoglalás}

A készült tanulmány bemutatja a szerkezetekre ható szeizmikus energia állapotát és kitér a szerkezeteknek a hagyományosan statikus és kinematikus paraméterek által meghatározott mechanikus állapotára. Az energia állapotát két tényező határozza meg: a szeizmikusan indukált energia és az inherens csillapítás által disszipált energia. Néhány számszerü, a romániai földrengések hatásait bemutató adatot tartalmaz. A tanulmány végkövetkeztetése szerint az energia állapota összefüggésben áll a többemeletes acélszerkezetek oldalsó merevségével és híven tükrözi mind a szerkezet merevsége és a földrengés által bevitt energia, mind a szerkezet merevsége és a disszipált energia viszonyát. A kutatás anyagi támogatását a Tartószerkezetmechanikai Tanszék biztosította.

Kulcsszavak: szeizmikus energia, acéltartó, merevség, bevitt energia.

\section{Bevezetés}

A szeizmikus zónákban [1] található szerkezetek energetikai szempontból való elemzése szükségességének felvetése pillanatától a szeizmikus analízis és az energetikai alapok szerinti tervezés gyors és extenzív fejlődésnek indult [2], [3], [4], [5]. A szeizmikus hatásoknak kitett szerkezeteknek energetikai alapon való elemzése a földrengési szerkezetbe bevitt energia mennyiségének valamint ezen energia szerkezeti elemei mennyiségének a kiértékeléséböl áll. Az $E_{i}$ szerkezetbe bevitt szeizmikus energia összetevői a következők:

- $\quad E_{k}$ a kinetikus energia;

- $E_{s}$ a rugalmas deformációs energia;

- $\quad E_{d}$ az inherens csillapítás által disszipált energia; 
- $E_{p} \quad$ a képlékeny deformáció által disszipált energia;

- $E_{a d}$ a hozzáadott csillapítás által disszipált energia.

A szerkezetek szeizmikus válaszának energetikai szempontból történő megközelítése az energetikai mérleg egyenletén alapszik:

$$
E i=E k+E s+E d+E p+E a d
$$

Rugalmas területen való viselkedés esetén a képlékeny területre való kitéréssel disszipált energiával társított $E_{p}$ fogalma érvénytelenné válik és az energetikai mérlegnek (1) a formája a következő lesz:

$$
E_{i}=E_{k}+E_{s}+E_{d}+E_{a d}
$$

Ha a szerkezet nincs ellátva a szeizmikus energia disszipálására alkalmas mechanizmusokkal, akkor az $E_{a d}$ érvény-telenné válik és az energetikai mérleg a legegyszerübb formára redukálódik:

$$
E_{i}=E_{k}+E_{s}+E_{d}
$$

A szerkezetben gerjesztett energia öszszetevői kihangsúlyozzák ennek az energiának a disszipációs lehetőségeit. A szeizmikus zónákban tervezett szerkezeteknek a tulajdonképpeni célja a szeizmikus input $E_{i}$ energiájának a disszipálása. Így könnyen megfigyelhetö, hogy az $E_{k}$ (kinetikus energia) és $E_{s}$ (rugalmas deformációs energia) szerkezeti fogalmak a mozgással ill. a struktúrának a szeizmikus rezgések következtében való deformációjával vannak aszszociálva. Egy olyan szerkezet esetén ami megfelel a statikus (erők) és kinematikus (deformációk) állapotra vonatkozó tervezési szabályozások által támasztott feltételeknek, az $E_{k}$ és $E_{s}$ nehezen megközelíthető a csillapítás szempontjából.

Ugyanakkor, a szerkezet inherens csillapítási tulajdonságai által keltett $E_{d}$ összetevő elérhetetlennek tekinthetö egy adott szerkezetre vonatkozólag.
Így az $E_{i}$ bevitt szeizmikus energia disszipálására két opció áll a tervező rendelkezésére: elfogadja az $E_{p}$ energetikai összetevőt létrehozó maradandó deformációkat és ellátja a szerkezetet az energiát disszipáló (az $E_{a d}$ összetevőt létrehozó) berendezésekkel. Az $E_{p}$ hatékony összetevö deformációkat feltételez és ezen keresztül nemcsak egy rugalmas-képlékeny mechanizmust, hanem a földrengés utáni nehézkes reabilitást is. Ebben az esetben az $E_{a d}$ összetevőt létrehozó passzív szeizmikus védelem (kiegészítő csillapítás) biztosítja a szeizmikus válasz csökkentését.

A kiegészítő csillapítással disszipált $E_{a d}$ energia mennyiségének növelése olyan eljárás, ami biztosítja a szeizmikus válasz csökkentését és ugyanakkor óvja a szerkezetet a képlékeny részek deformálódásától. A rugalmas zóna tulajdonságai és, ezzel egyidőben, a szeizmikus válasz csökkentése képezik az ideális szerkezeti tervezést és a gazdaságos keresztmetszeti méretezést.

\section{Energetikai összetevők}

A bevitt (input) szeizmikus energia és szerkezeti összetevői követik a "Rezgések mechanikájára" [2], [3], [6] jellemző energetikai fejlődést. Ugyanakkor a bevitt szeizmikus energia és szerkezeti alkotói meghatározásánál számításba veszik a dinamikus modellt, egy vagy több szabadsági fokkal. Bármelyik is a dinamikus modell, az energiát meghatározó fogalmak skaláris paraméterek, így lehetséges a skaláris müveletek tulajdonságainak az alkalmazása ami előnyt jelent a szeizmikus hatás alatt álló szerkezet mechanikus állapotának a meghatározásában az igénybevétel bármely pillanatában.

\subsection{Az egy szabadsági fokkal rendel- kező rendszerek}

Az egy szabadsági fokkal rendelkező rendszer dinamikus modellje az 1. ábrán látható paramétereket feltételezi. 


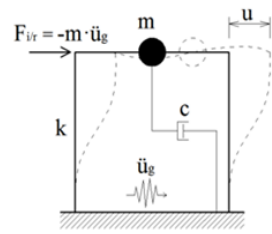

$\mathrm{m}$ - koncentrált tömeg

$\ddot{\mathrm{U}}_{\mathrm{g}}(\mathrm{t})$ - a terület (feljegyzett) gyorsulása

$\mathrm{k}-\mathrm{a}$ dinamikus rendszer oldalsó merevsége

c- a rendszer viszkózus csillapítási együtthatója

$\mathrm{u}(\mathrm{t})$ - a dinamikus szabadság foka

1.ábra. Egy szabadság fokú dinamikus rendszer.

A szeizmikus terhelés alatt álló rendszer viselkedésével összefüggő energiák kifejezhetők a következőképpen [2], [3]:

$$
\begin{gathered}
E_{i}=-\int_{0}^{u} m \cdot \ddot{u}_{g}(t) \cdot d u= \\
=-\int_{0}^{t} m \cdot \ddot{u}_{g}(t) \cdot \dot{u} \cdot d t \\
E_{k}=\int_{0}^{u} m \cdot \ddot{u}(t) \cdot d u=\frac{1}{2} \cdot m \cdot(\dot{u})^{2} \\
E_{d}=\int_{0}^{t} c \cdot[\dot{u}(t)]^{2} \cdot d t \\
E_{s}=\int_{0}^{t} k \cdot u(t) \cdot \dot{u}(t) \cdot d t
\end{gathered}
$$

\subsection{Az n véges számú szabadsági fok- kal rendelkező rendszerek}

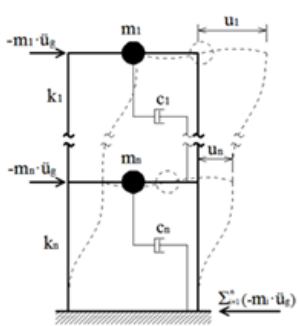

$$
\begin{aligned}
& \mathbf{M} \text { - tömegmátrix } \\
& \mathbf{u} \text { - a szabadsági fokok n vektora } \\
& \mathbf{K} \text { - merevségi mátrix } \\
& \mathbf{C} \text { - csillapítási mátrix } \\
& \mathrm{u}(\mathrm{t}) \text { - sebességi vektor } \\
& \mathrm{u}(\mathrm{t}) \text { - gyorsulási vektor } \\
& \ddot{\mathrm{u}}_{\mathrm{g}}(\mathrm{t}) \text { - területi gyorsulás }
\end{aligned}
$$

2. ábra. Az n szabadság fokú dinamikus modell.

Ezeknek a rendszereknek a dinamikus modellje a födémek szintjén összpontosuló $m_{i}$ tömegủ és $n$ szabadsági fokú, ahol $u_{i}-$ az $m_{i} \quad$ tömegek oldalirányú elmozdulása (2. ábra).

Ezzel a modellel asszociált vektoriális és mátrixszerü paraméterek a 2. ábrán látha- tók. E dinamikus modellnek megfelelö energiák kifejezési formája [2], [3] a következő $\left(E_{i / r}\right.$ a bevitt szeizmikus energia, $E_{k / r}$ a kinetikus energia, $E_{d}$ a viszkózus csillapítás által disszipált energia és $E_{s}$ a rugalmas és képlékeny alakváltozási energia):

$$
\begin{gathered}
E_{i / r}=-\int_{0}^{t}(\dot{u})^{T} \cdot M \cdot \ddot{u}_{g}(t) \cdot d t= \\
=-\int_{0}^{u}(\dot{u})^{T} \cdot M \cdot d \dot{u}_{g}(t) \\
E_{k / r}=\int_{0}^{t}(\ddot{u})^{T}(t) \cdot M \cdot \dot{u} \cdot d t= \\
=\int_{0}^{u}(\ddot{u})^{T}(t) \cdot M \cdot d u=\frac{1}{2} \cdot\left(\dot{u}^{T} \cdot M \cdot \dot{u}\right) \\
E_{d}=\int_{0}^{t}(\dot{u})^{T}(t) \cdot C \cdot \dot{u} \cdot d t \\
E_{s}=\int_{0}^{t}(u)^{T}(t) \cdot K \cdot \dot{u} \cdot d t= \\
=\int_{0}^{u}(u)^{T}(t) \cdot K \cdot d u
\end{gathered}
$$

\section{Néhány számszerű eredmény}

A (4) és (5) integrálok eredményének grafikus ábrázolása pontosabb képet nyújt a szeizmikus hatásoknak kitett szerkezetek energetikai állapotáról. Az eredmény egy sík acélkeretü, többféle oldalirányú merevségi helyzetü (merev, mérsékelt, hajlékony) szerkezeten kerül bemutatásra (3. ábra).
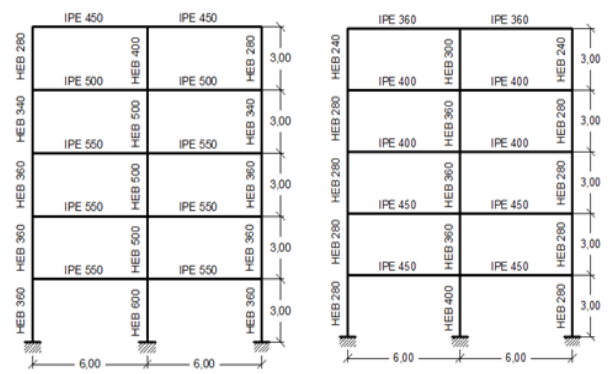

3. ábra. A szerkezet merev és hajlékony helyzetben. 
Az alkalmazott szeizmikus hatás a '86-os Focșani-i és '77-es Vrancea-i földrengés. Az oldairányú merevségi állapot kifejezhető az alapvető rezgési periódus $T_{1}$ értékével a három különböző helyzetben: $T_{1}$ $=0,65 \mathrm{~s}$ (merev szerkezet); $T_{1}=0,76 \mathrm{~s}$ (mérsékelten merev szerkezet); $T_{1}=0,94 \mathrm{~s}$ (hajlékony szerkezet).
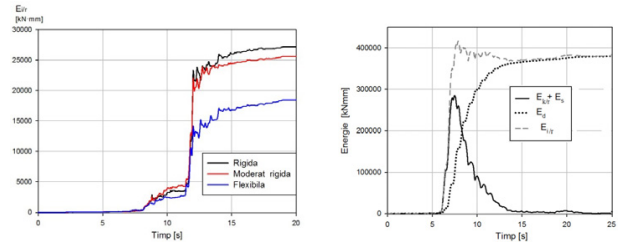

5. ábra. Bevitt szeizmikus energia vs. oldalirányú merevség - Focsani '86 (balra); Bevitt szeizmikus energia és összetevöi - Vrancea '77(jobbra).

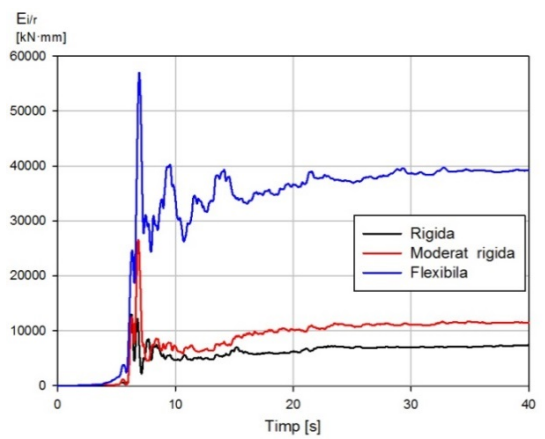

6. ábra. Energetikai input vs. oldalirányú merevség - Vrancea' 77.

A bevitt szeizmikus energiának megfelelö eredmények három oldalirányú merevségi esetben (5. ábra, balra) kerülnek összehasonlításra. Ugyanakkor, az eredmények nemcsak az $E_{i}$ bevitt energiára vonatkoznak, hanem annak összetevőire is (5. ábra, jobbra). A szerkezet energetikai állapotát nagymértékben befolyásolja a szerkezet oldalirányú merevsége és a szeizmikus hatás. Így, a merev szerkezet esetében a '86os Focşani-i földrengés által gerjesztett szeizmikus energia eléri az $E_{i}=25$ GJ (5. ábra, balra) értéket, míg a '77-es Vrancea-i föld- rengés energiája jóval meghaladja azt: $E_{i}=57 \mathrm{GJ}$ (6. ábra).

\section{Következtetések}

Az energetikai állapot világosan és egyszerúen kifejezi a szeizmikus választ. A számszerüen bemutatott eredmények kiemelik, hogy az energetikai állapotot két tényező határozza meg: a szerkezet merevsége és a szeizmikus hatás. A szeizmikus energia kiszámításának az egyszerüsége, valamint a szeizmikus válasz energetikai kifejezéseinek a sokoldalúsága amellett szólnak, hogy az energetikai állapot kiegészítésként figyelembe legyen véve a csupán statikus és kinematikus helyzetet magába foglaló mechanikus állapot mellé.

\section{Szakirodalmi hivatkozások}

[1] Housner, G. W.: Limit design of structures to resist earthquakes, Proceedings of the 1st World Conference on Earthquake Engineering, Berkeley Calif., 1956.

[2] Uang, C. M.; Bertero, V. V.: Evaluation of seismic energy in structures, Earthquake Engineering and Structural Dynamics, Vol. 19, 1990, pp. 77-90.

[3] Bertero, V. V.; Teran-Gilmore, A.: Use of energy concepts in earthquake - resistant analysis and design: Issues and future directions, Memorias del VIII Seminario Latinoamericano de Ingenieria Sismoressis-tente y Primeras Jornadas de Ingenieria Estructural, Merida, Venezuela, 5-8 Julio de 1993.

[4] Chopra, A. K.: Dynamics of Structures. Theory and Applications to Earthquake Engineering. Prentice Hall International, 1995.

[5] Chou, C. C.; Uang, C. M.: An evaluation of seismic energy demand: an attenuation approach, PEER Report: 04, 2000.

[6] Decanini, L.; Mollaioli, F.; Mura, A.: Equivalent SDOF systems for the estimation of seismic response of multi-storey frame structures, Earthquake Resistant Engineering Structures, III, 2001, pp.101-110.

Acknowledgment: the publication fee was supported by the Department of Structural Mechanics, from the T.U. of Cluj-Napoca. 